\title{
Epstein-Barr Virus-infected T Lymphocytes in Epstein-Barr Virus-associated Hemophagocytic Syndrome
}

\author{
Hiroyuki Kawaguchi, * Toshiyuki Miyashita, * Hermann Herbst, ${ }^{*}$ Gerald Niedobitek, ${ }^{*}$ Minoru Asada, * Masahiro Tsuchida," \\ Ryouji Hanada," Akitoshi Kinoshita," Minoru Sakurai, * " Noboru Kobayashi, " and Shuki Mizutani * \\ ${ }^{*}$ Department of Virology, The National Children's Medical Research Center, Tokyo 154, Japan; ${ }^{\ddagger}$ Institute of Pathology, Klinikum \\ Steglitz, Free University of Berlin, Berlin 45, Germany; ${ }^{8}$ Department of Internal Medicine, Ibaraki Children's Hospital, Ibaraki 311-41, \\ Japan; "Department of Hematology/Oncology, Saitama Children's Medical Center, Saitama 339, Japan; 'Department of Pediatrics, \\ Keio University of Medical School, Tokyo 160, Japan; ** Department of Pediatrics, School of Medicine, Mie University, \\ Mie 514, Japan; and ${ }^{\ddagger}$ The National Children's Hospital, Tokyo 154, Japan
}

\begin{abstract}
The clonal composition of EBV-infected cells was examined in three cases of EBV-associated hemophagocytic syndrome by analysis of the heterogeneity of terminal repetitive sequences in the EBV genome, indicating monoclonal expansion of EBV-infected cells in all cases. Involvement of $T$ lymphoid cells was determined by in situ hybridization using ${ }^{35}$ S-labeled RNA probes specific for the small EBV-encoded nuclear RNAs, EBER1 and EBER2, in combination with immunostaining for the TCR- $\beta$ chain, CD45RO, CD20, CD30 and CD68 antigens in these three cases. The majority of lymphoid cells showing EBER transcripts were stained by antibodies against CD45RO and $T$ cell receptor- $\beta$. In contrast, $E B E R$-specific signals were not detectable on $B$ cells or hemophagocytic cells. These data support the concept that EBV-associated T cell proliferation is a primary feature of EBV-AHS. (J. Clin. Invest. 1993. 92:1444-1450.) Key words: T cells • CD45RO antigen • EBER • malignant histiocytosis • histiocytic medullary reticulosis
\end{abstract}

\section{Introduction}

Virus-associated hemophagocytic syndrome (VAHS) ${ }^{1}$ is a histiocytic proliferative disorder associated with viral infection (1, 2). Clinically, patients with VAHS have high fever, skin rash, hepatosplenomegaly, pancytopenia, and coagulopathy, and morphologic examination of lymph node and bone marrow demonstrates prominent phagocytosis of erythrocytes and nucleated blood cells. In contrast to malignancies considered to

The present address of Gerald Niedobitek is Department of Pathology, University of Birmingham, Birmingham B15 2TT, UK.

Address correspondence to Dr. Shuki Mizutani, Department of Virology, The National Children's Medical Research Center, 3-35-31, Taishido, Setagaya-ku, Tokyo, 154 Japan. 1993.

Received for publication 6 January 1993 and in revised form 9 April

1. Abbreviations used in this paper: $\mathrm{BM}$, bone marrow; $\mathrm{EA}$, early antigen; EBNA, Epstein-Barr nuclear antigen; EBV-AHS, Epstein-Barr virus-associated hemophagocytic syndrome; MNC, mononuclear cell; PB, peripheral blood; TCR, T cell receptor; VAHS, virus-associated hemophagocytic syndrome; VCA, viral capsid antigen.

J. Clin. Invest.

(C) The American Society for Clinical Investigation, Inc.

0021-9738/93/09/1444/07 \$2.00

Volume 92, September 1993, 1444-1450 be of histiocytic origin, such as malignant histiocytosis ( 3 ) and histiocytic medullary reticulosis (4), the accumulation of phagocytosing histiocytes in VAHS is thought to be a reactive condition, although the pathogenesis of this process is poorly understood.

Among various infectious agents, herpesviruses, particularly EBV, have been implicated in the pathogenesis of VAHS $(1,2)$. EBV is a ubiquitous pathogen in human populations throughout the world. Infection is usually not associated with clinical disease except for infectious mononucleosis in developed countries. EBV-infected B cells are immortalized and persist in the host for life. The virus is also associated with various types of malignancies such as Burkitt lymphoma, nasopharyngeal carcinoma (5), T cell lymphoma $(6,7)$, and polyclonal B cell lymphoproliferation (8) in immunosuppressed individuals. We report here that in cases of EBV-associated hemophagocytic syndrome (EBV-AHS) there is a clonal proliferation of EBV-infected T cells but not of EBV-infected B cells or histiocytes. We propose that these EBV-infected T cells may be responsible for causing the clinical features of EBV-AHS.

\section{Methods}

Case reports. The clinical and laboratory data of the three cases studied are given in Table I and Results. All three patients had high fever, profound pancytopenia, and hepatosplenomegaly. Laboratory data demonstrated that they also had extreme hyperferritinemia, liver dysfunction, and coagulation abnormalities. The bone marrow was hypocellular and proliferation of either immature (cases B and C) or mature (case A) histiocytic cells with prominent hemophagocytosis was seen in all cases. None of the patients had any preexisting disease or immunodeficient condition. The clinical course was rather rapid, except for case A, who had repeated occurrences of the disease over a period of $20 \mathrm{mo}$. The clinical and laboratory data of case $A$ have been reported previously (9). The association with EBV was suggested by the elevation of anti-EBV antibodies in cases $A$ and $C$ (Table $I B$ ).

Serological studies for $E B V$. Antibody titers against EBV-viral capsid antigen (VCA), early antigen (EA), and Epstein-Barr nuclear antigen (EBNA) were determined by established methods (10).

Cells, tissues, and DNA preparation. Mononuclear cells (MNCs) were separated from heparinized peripheral blood (PB) and/or bone marrow (BM) by a density gradient of Ficoll-Metrizoate (Lymphoprep; Nygaard, Oslo, Norway) centrifugation. High molecular weight DNA was extracted from BM MNCs and PB MNCs according to the method described previously (11). Formol-fixed/paraffin-embedded autopsy specimens of BM from case A, BM and lymph node from case $B$, and liver from case $C$ were available for study by in situ hybridization.

Southern hybridization. Aliquots of $10 \mu \mathrm{g}$ of genomic DNA were digested with 3-5 U/ $\mu$ g of restriction enzyme BamHI (Takara Shuzou, Kyoto, Japan), electrophoresed on $\mathbf{0 . 7 \%}$ agarose gels, and transferred to Gene Screen Plus membrane (NEN Research Products, Boston, 
Table I. Clinical (A) and Laboratory (B) Data of the Patients with the Diagnosis of EBV-AHS

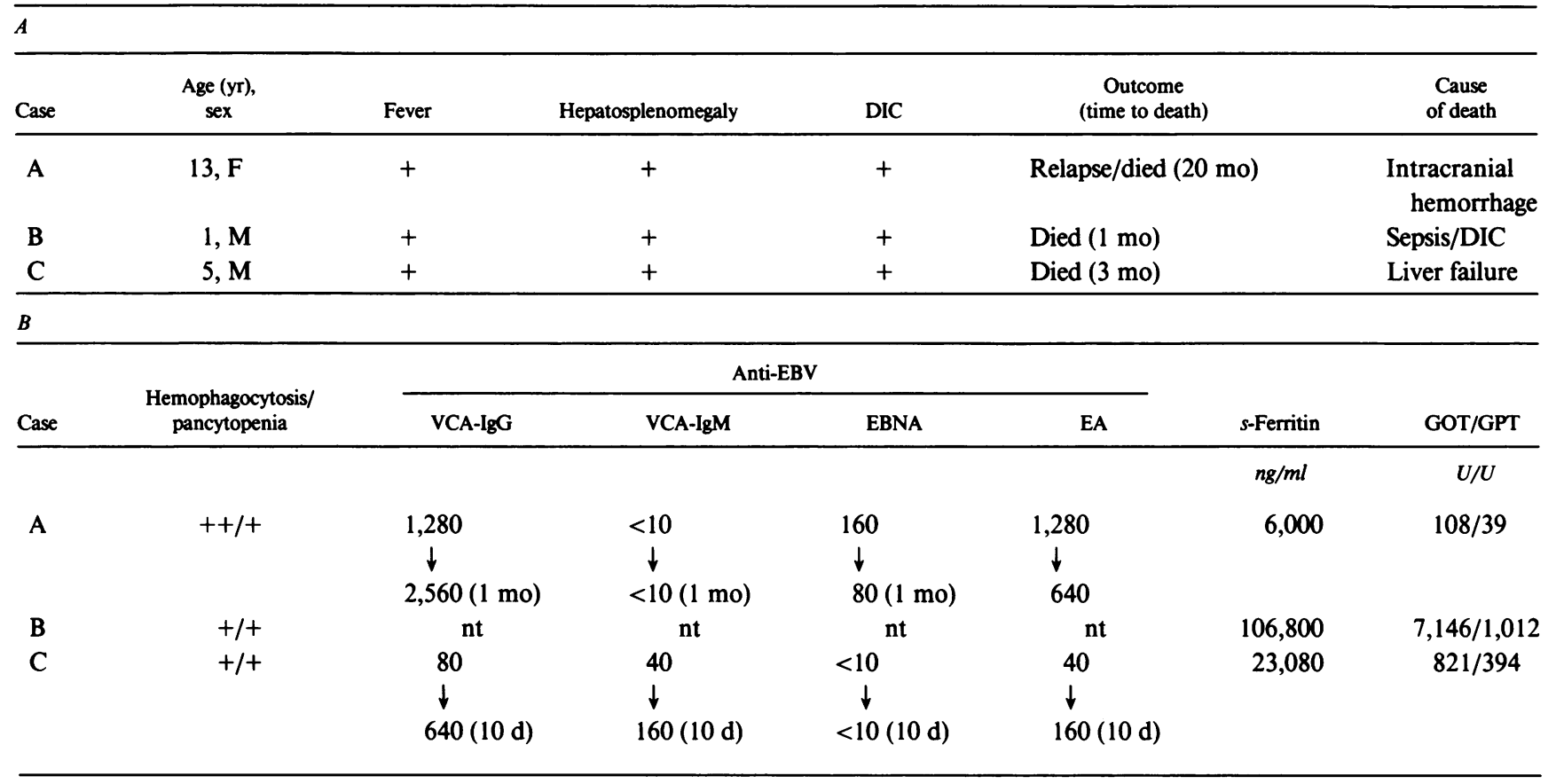

F, female; M, male; DIC, disseminated intravascular coagulopathy.

MA). Blots were hybridized with a ${ }^{32} \mathrm{P}$-labeled hybridization probe, 1.9-kb Xhol, which detects the terminal repeat fragment of EBV (5). This probe detects clonally infected cells and distinguishes episomal from linear viral DNA. Southern hybridization was carried out according to the method described previously (11). For the analysis of immunoglobulin heavy chain $(\mathrm{IgH})$ gene, T cell receptor $\beta$ (TCR- $\beta$ ) chain gene, and TCR- $\gamma$ chain gene, an IgJH probe (5.8-kb BamHI-HindIII fragment, $\lambda \mathrm{CH} 28-6 ; 12), \mathrm{C} \beta$ probe $(0.3-\mathrm{kb}$ StuI fragment, SP64; 13), and $\mathrm{J}_{\gamma}$ probe (HindIII fragment, $\mathrm{M} 13 \mathrm{H} 60 ; 14$ ) were used, respectively.

Karyotype analysis. BM MNCs were cultured for $24 \mathrm{~h}$ without stimulation. Chromosomes were analyzed with regular Giemsa staining and G- and Q-banding methods. Karyotypes were described according to ISCN (1985) (15).

Immunohistology and in situ hybridization. The production and specificity profiles of the monoclonal antibodies specific for LMP1 (clones CS1, $-2,-3$, and -4 ) are described elsewhere (16). To define the cellular lineage of EBV-infected cells, double labeling was performed by in situ hybridization to the EBV-encoded small RNAs EBER 1 and EBER2 (17), in combination with immunostaining for TCR- $\beta$, CD45RO ( 18)( $T$ cell antigens), CD20 ( $B$ cell antigen ), CD68 ( macrophage/histiocytic antigen), and CD30 (activation marker) (19-21). Monoclonal antibodies against CD20 (L26), CD30 (Ber-H2), and CD68 (KP-1) were obtained from Dakopatts (Glostrup, Denmark). The anti-TCR- $\beta$ chain antibody, $\beta \mathrm{F} 1$, was from $\mathrm{T}$ Cell Sciences, Inc. (Cambridge, MA), and the CD45RO-specific antibody A6 was a kind gift of Dr. G. G. Aversa (Stanford University, Stanford, CA). 4- $\mu \mathrm{m}$ sections of formol-fixed, paraffin-embedded tissue blocks were stained by the immunoalkaline method (22). Affinity-purified rabbit antimouse Ig antibody and alkaline phosphatase-anti-alkaline phosphatase complex (diluted 1:20) were obtained from Dakopatts. After visualization of immobilized antibodies, slides were immediately subjected to the in situ hybridization procedure. In situ hybridization protocol was the same as described previously $(20,21)$. Briefly, EBER1- and EBER2-specific fragments were derived from the plasmids pJJJ1 and pJJJ2, kindly provided by Dr. J. Arrand (Paterson Institute, Manchester, UK) and subcloned into the BamHI/EcoRI and EcoRI/HindIII sites, respectively, of the transcription vector BluescriptKS. After linearization with the appropriate restriction enzymes, ${ }^{35}$ S-labeled anti- sense or sense (control) run-off transcripts were generated using either T3 or T7 RNA polymerase and [ ${ }^{35}$ S ] uridine $5 '-(\alpha$-thio) triphosphate $(1,250 \mathrm{Ci} / \mathrm{mmol}$; New England Nuclear, Dreieich, FRG). A mixture

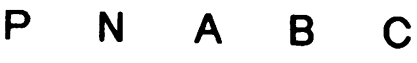

[kb]

23.6 -

$9.6-$

6.6

$4.3-$

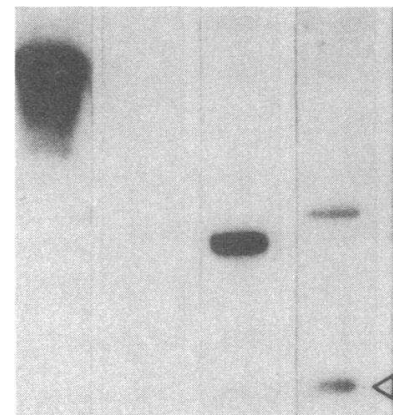

2.2 -

2.0

Figure 1. Southern blot hybridization. Southern hybridization using a ${ }^{32}$ P-labeled probe representing the 1.9-kb Xhol fragment of EBV. Monoclonal proliferation of EBV-infected cells is indicated by the single high molecular weight band. Additionally, case B has a low molecular weight band (arrowhead), probably indicating an integrated EBV DNA (see Discussion). Lane 1, Raji; lane 2, HL60; lane 3, BM-MNC of case A; lane 4, BM MNC of case B; lane 5, BM-MNC of case $C$. Arrowhead represents linear form termini fragment. 

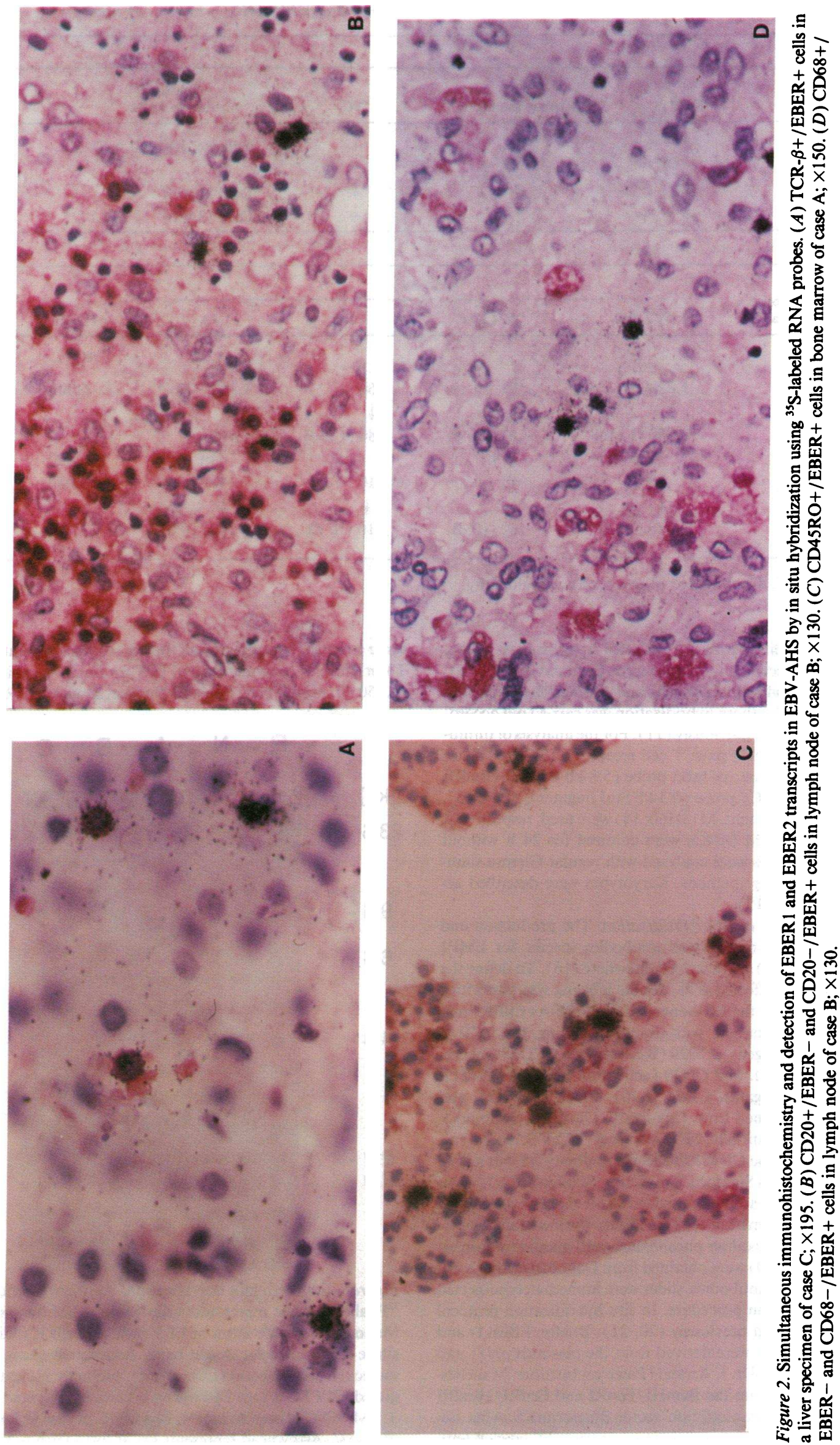

5

尊

$\approx$

兽

疍

思

舟这

50

政

政

政

至至

政

ชิ

(1)

$\frac{3}{x}$

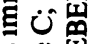

苨焉

吹

光

क है

ข 1

运置 
of EBER1- and EBER2-specific RNA probes was applied to increase the sensitivity.

\section{Results}

Case A had elevated anti-EBNA, VCA-IgG, and EA titers, which suggests that the disease was not associated with primary EBV infection. On the other hand, case $\mathrm{C}$ showed absence of anti-EBNA antibody with the presence of VCA-IgM, indicating a primary EBV infection. By Southern hybridization analysis on the BamHI-digested DNA extracted from BM MNCs, discrete single bands $>7 \mathrm{~kb}$ were detected using the 1.9-kb XhoI probe (Fig. 1). This suggests that each sample contains a single episomal form of EBV and agrees with the interpretation that EBV-infected cells proliferate monoclonally. An additional 4.5-kb single band was found in case $B$.

The histologic features, in situ hybridization, and immunohistology patterns are shown in Fig. 2 and summarized in Table II. Colocalization of EBER-specific hybridization signals with $\mathrm{T}$ cell-specific immunolabeling (CD45RO, TCR- $\beta$ ) was seen in $\sim 9$ out of 10 EBER-positive cells (cases B and C). In case A, with respect to EBER-positive cells, the percentage of CD45RO-positive cells exceeded that of TCR- $\beta$-positive cells. The cytological features of the EBER-positive $T$ cells in the tissues either exclusively (cases B and C) or predominantly (case A) showed the morphology of small lymphocytes (Fig. 3).

Moderate numbers of CD20-positive cells were found in all tissues, however, not in association with the EBER-specific signal. Thus, 10\% of the EBER-positive cells could not be characterized by immunohistology, and the lineage of these cells remains undefined. CD68-positive cells did not display any cellular or nuclear atypia. CD68 and EBER labeling was exclusive in all the cases. No positive staining was observed with antibodies against CD30 or LMP1 on formol-fixed sections in any of the samples using formol-fixed lymph node specimens of $\mathrm{Ki}-1$ positive anaplastic large cell lymphoma as positive control.
These three cases were studied for antigen receptor gene rearrangement. The IgH, TCR- $\beta$, and TCR- $\gamma$ gene configurations were germ line (data not shown), ruling out the presence of a predominant clonal population of cells with clonal rearrangement of these antigen receptor genes.

Karyotype was studied in cases $A$ and $C$ and showed normal 46, XX and 46, XY, respectively.

\section{Discussion}

Three EBV-AHS cases were examined by Southern analysis for the presence of EBV and the structure of the EBV genome using probes for the viral terminal restriction fragment. In all three cases, a discrete single band $>7 \mathrm{~kb}$ was observed, consistent with monoclonal episomal viral DNA. An EBV structure identical to that observed in BM MNCs was also seen in PB MNCs in cases A and C (data not shown), suggesting that the progenitor cell of EBV infection is common between PB and $\mathrm{BM}$ in these cases. The uniformity of the EBV genome in each of the cases implies the presence of a population of cells containing one particular episomal form of EBV DNA. This suggests that EBV-infected cells proliferate monoclonally in EBVAHS. The repeated occurrence of the same EBV-infected cell clone reported elsewhere (9) may also argue for the persistence of the same EBV-infected clone throughout the course of the disease.

An additional 4.5-kb single band was found in case B. Although the interpretation of this additional band is not clear, it is unlikely that this band represents a linear form of EBV DNA, as a linear DNA is usually seen as a ladder of terminal fragments (23). It is more likely that this band indicates an integration of EBV genome into an unidentified locus of host DNA in the clonally proliferating cells. The clinical significance of this finding needs to be studied.

In contrast to malignancies considered to be of histiocytic origin, such as malignant histiocytosis and histiocytic medullary reticulosis, the pathogenesis of the accumulation of phago-

Table II. Summary of Histological Findings and Laboratory Data

\begin{tabular}{|c|c|c|c|c|c|c|c|}
\hline Patient & Materials & $\begin{array}{l}\text { Histology/ } \\
\text { cytology }\end{array}$ & $\begin{array}{l}\text { TCR- } \beta \text { and EBER } \\
\text { coexpression }\end{array}$ & $\begin{array}{l}\text { CD45RO and } \\
\text { EBER } \\
\text { coexpression }\end{array}$ & $\begin{array}{l}\text { EBER and } \\
\text { CD20 } \\
\text { coexpression }\end{array}$ & $\begin{array}{l}\text { EBER and } \\
\text { CD68 } \\
\text { coexpression }\end{array}$ & LMP1 \\
\hline Case A & $\mathrm{BM}$ & $\begin{array}{l}\text { Hypocellular marrow } \\
\text { Prominent hemophagocytic cells } \\
\text { Relative increase of small to } \\
\text { medium sized lymphocytes }\end{array}$ & $70 \%$ & $>80 \%$ & None & None & None \\
\hline \multirow[t]{2}{*}{ Case B } & BM & $\begin{array}{l}\text { Hypocellular marrow } \\
\text { Relative increase of lymphocytes } \\
\text { Prominent hemophagocyctic cells }\end{array}$ & $80 \%$ & $90 \%$ & Very few & None & None \\
\hline & Lymph node & $\begin{array}{l}\text { Depletion of lymphocytes } \\
\text { Few lymphocytes in the } \\
\text { interfollicular area and atrophic } \\
\text { follicles } \\
\text { Prominent hemophagocytic cells }\end{array}$ & Majority & Majority & None & None & None \\
\hline Case C & Liver & $\begin{array}{l}\text { Retained lobular architecture } \\
\text { Portal, sinusoidal, and } \\
\text { pericentrovenular infiltration by } \\
\text { small lymphocytes }\end{array}$ & Majority & Majority & None & None & None \\
\hline
\end{tabular}

LMP1, latent membrane protein 1. 

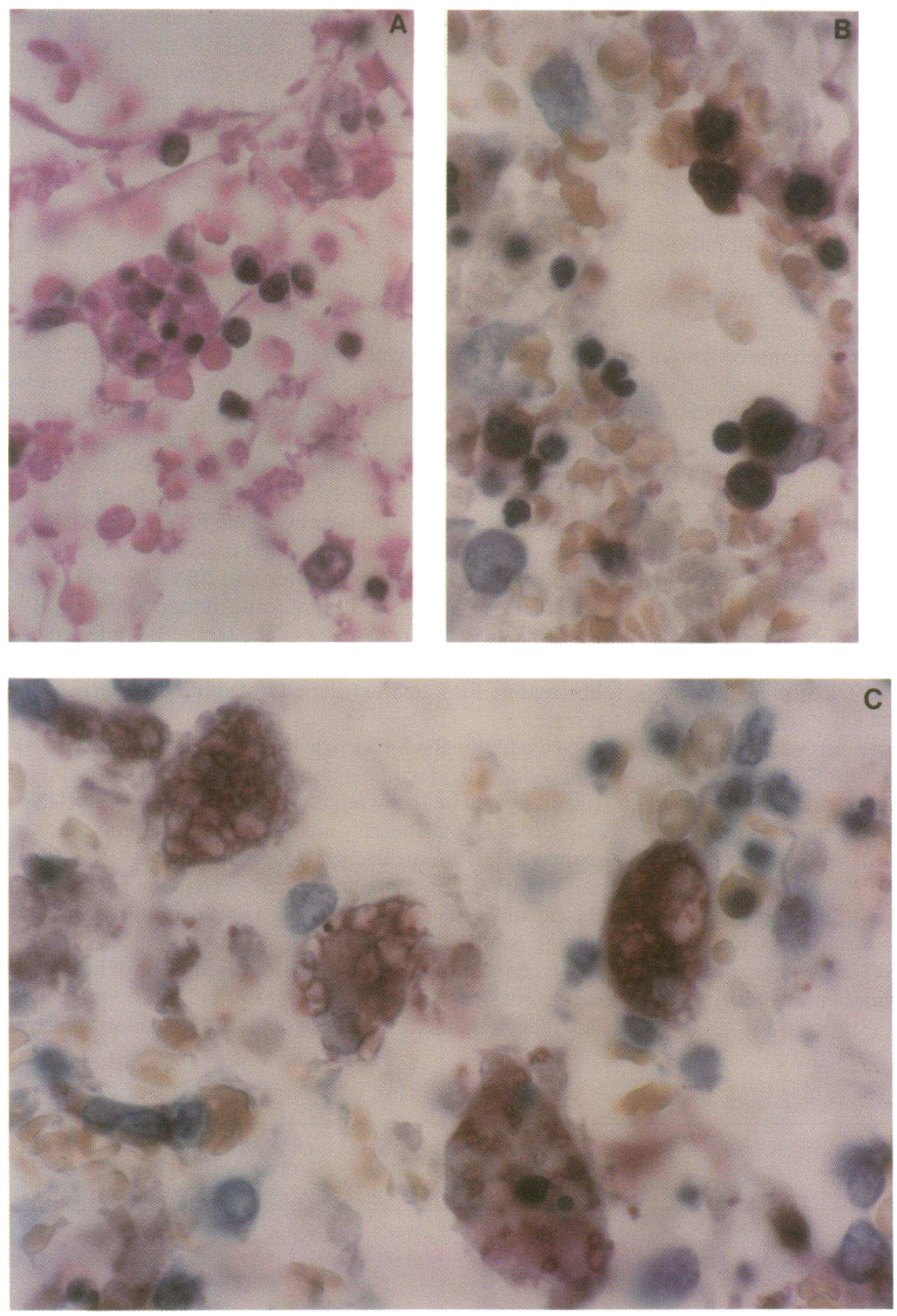

Figure 3. Hematoxilyn and eosin stain and immunohistochemical stain for EBV-AHS samples. $(A)$ Hematoxilyn and eosin stain for a BM specimen of case B displaying hemophagocytic cells with multiple ingested nucleated cells $(\times 250)$. (B) $\beta \mathrm{T} 1$ (TCR $\beta$ chain) stain for a $B M$ specimen of case $B(\times 250)$, displaying $T$ cells (X250). (C) KP-1 (CD68) stain for a BM specimen of case B, displaying hemophagocytic cells with multiple ingested nucleated cells or red blood cells $(\times 250)$.

cytosing histiocytes in EBV-AHS is poorly understood. In this study, in situ hybridization and immunostaining results demonstrated that CD45RO-positive T cells are infected with EBV. Considering the observation that EBV-infected cells proliferate monoclonally in EBV-AHS, a reasonable conclusion is that these clonal cells are EBV-infected CD45RO-positive $T$ cells. Although the EBV-infected $\mathrm{T}$ cells may be monoclonal with respect to the structure of the viral genome, no clonal rearrangement of TCR $-\beta$ or $-\gamma$ genes was detected by Southern hybridization in these cases. This may be due to the involvement of only a small number of EBV-infected T cells in the samples used for DNA extraction below the threshold of detection with the TCR genes. This is plausible since the viral DNA may be amplified up to 100 -fold in infected cells, whereas the antigen receptor genes are only present as a single copy. An alternative explanation is that EBV infection of T cells may have occurred before rearrangements of TCR genes, so that EBV-harboring T cells may possess an oligoclonal composition in some cases of EBVAHS. It remains to be determined whether these clonally expanded EBV-infected $T$ cells represent proliferations of nontransformed $T$ cells or whether, at least in some cases, they are manifestations of a peripheral $\mathrm{T}$ cell lymphoma of low malignancy. However, the cytological characteristics of the EBERpositive $T$ cells in the tissues, showing either exclusively (cases $B$ and $C$ ) or predominantly (case A) the morphology of small lymphocytes, are clearly different from the cases reported as 
"peripheral $\mathrm{T}$ cell lymphoma with hemophagocytic syndrome" (24) or the case reported by Craig et al., considered to represent a $\mathrm{T}$ cell lymphoma with underlying EBV infection (25), although the accumulation of hemophagocytic cells is similarly associated with underlying $\mathrm{T}$ cell disease in both our cases and theirs. Many cases of EBV-AHS exhibit a clinically benign course, while others show a more aggressive manifestation of the disorder with repeated occurrences of the EBV-harboring cell clone (9). This favors the view that the EBV-infected T cells in EBV-AHS represent a range from preneoplastic to overtly malignant proliferations.

In the light of the recent findings that CD45RO-positive mature T cells produce cytokines such as IL-2, IL-3, IL-4, IL-5, IL-6, and IFN- $\gamma(26-28)$, together with the findings that inflammatory cytokine levels such as IFN- $\gamma$, TNF, and IL- 6 are elevated in hemophagocytic syndrome $(29,30)$, a systemic hypercytokinemia caused by the proliferation of EBV-infected T cells may play a critical role in the development of this disorder. The pathophysiological role in the complex regulation of serum cytokine secretion of the EBV protein BCRF1, which mimics the activity of cytokine synthesis inhibitory factor (IL10) (31), needs to be studied. In situ identification of cytokine expression in affected $\mathrm{T}$ cells will shed light on the in vivo clinico-pathological features of the histiocytic proliferation in relation to the cytokines produced by T cells. CD68 and EBER labeling in EBV-AHS samples was exclusive in all cases, confirming that histiocytic accumulations and proliferations were not directly mediated by EBV infection. Because of the benignappearing histology and absence of $\mathrm{CD} 30$ antigen expression, anaplastic large cell lymphoma with an exuberant hyperplasia of reactive histiocytes (32) can be excluded.

LMP1, a cell cycle-dependent viral transforming protein that upregulates bcl-2 in B cells $(33,34)$, was not expressed. However, only paraffin-embedded material could be used for our immunohistological studies. Therefore, low levels of LMP1 expression in some of the cases cannot be excluded. In light of the otherwise frequent association of LMP1 with CD30 expression, LMP1 expression by the CD30-negative $T$ cells in VAHS appears to be less likely. A definitive answer to the questions of LMP1 expression and the presence of other EBV gene products such as EBNA2 or BZLF1 protein will require the use of fresh tissue samples. A more detailed analysis of the viral gene expression pattern in EBV-AHS is necessary to define the role for EBV in the pathoetiology of the disease more precisely.

On the basis of our data, proliferations of EBV-infected T cells must be regarded as a primary feature of EBV-AHS. Our findings suggests that $\mathrm{EBV}$-infected $\mathrm{T}$ cells might induce the accumulation and the phagocytosing behavior of histiocytes and macrophages. Such phagocytic histiocytes have not been recognized in the few examples of EBV-infected $T$ cell diseases, including most $T$ cell lymphomas $(6,7)$, lethal midline granuloma (35), and Kawasaki-like disease (36). Thus, EBV-AHS represents a subset of EBV-infected $\mathrm{T}$ cell diseases characterized by the accumulation and proliferation of hemophagocytic macrophages, as has been recognized in a particular type of $T$ cell lymphoma (24). The results of our study also have important implications for the treatment of this disorder. The treatment strategy for EBV-AHS should include methods to eradicate EBV-infected T cells as well as hemophagocytic histiocytes.

\section{Acknowledgments}

We are grateful to Drs. N. Raab Traub, P. Leder, T. Mak, T. Rabbits, and J. Arrand for the EBV 1.9-kb terminal repeat probe, IgJH, TCR- $\beta$, TCR- $\gamma$, and EBER plasmids, respectively. We thank Dr. L.C. Chan for the critical reading of this manuscript. We are also grateful to Teresa Finn for her technical assistance.

This work was supported by a Grant-in-Aid for Cancer Research from the Ministry of Health and Welfare, Japan, and by a Grant-in-Aid from the Ministry of Health and Welfare, Japan, as part of a comprehensive 10-year strategy for cancer control; by a Grant-in-Aid from the Ministry of Education, Science and Culture, Japan; by a grant from the Human Science Foundation, Japan; and by a grant from Deutsche Krebshilfe, Germany. H. Kawaguchi is a research fellow supported by the Human Science Foundation in Japan.

\section{References}

1. Risdall, R. A., R. W. Meckenna, M. E. Nesbit, W. Krivit, H. H. Balfour, R. L. Simmons, and R. D. Brunning. 1979. Virus-associated hemophagocytic syndrome. Cancer (Phila.) 44:993-1002.

2. McKenna, R. W., R. J. Risdall, and R. D. Brunning. 1981. Virus associated hemophagocytic syndrome. Hum. Pathol. 12:395-398.

3. Byrne, G. E., Jr., and H. Rappaport. 1973. Malignant histiocytosis. Gann Monogr. Cancer Res. 15:145-162.

4. Scott, R. B., and A. H. T. Robb-Smith. 1939. Histiocytic medullary reticulosis. Lancet. ii:194-198.

5. Raab-Traub, N., and K. Flynn. 1986. The structure of the termini of the Epstein-Barr virus as a marker of clonal cellular proliferation. Cell. 47:883-889.

6. Jones, J. F., S. Shurin, G. Abramowsky, R. Tubbs, G. Sgiotto, R. Wahl, J. Sands, D. Gottman, B. Z. Katz, and J. Sklar. 1988. T-cell lymphomas containing Epstein-Barr viral DNA in patients with chronic Epstein-Barr virus infection. $N$. Engl. J. Med. 318:733-741.

7. Su, I. J., H. C. Hsieh, K. H. Lin, W. C. Uen, C. L. Kao, C. J. Chen, A. L. Cheng, M. E. Kadin, and J. Y. Chen. 1991. Aggressive peripheral T-cell lymphomas containing Epstein-Barr viral DNA. A clinicopathological and molecular analysis. Blood. 77:799-808.

8. Cleary, M. L., M. A. Nalesnik, W. T. Shearer, and J. Sklar. 1988. Clonal analysis of transplant-associated lymphoproliferations based on the structure of the genomic termini of the Epstein-Barr virus. Blood. 72:349-352.

9. Miyashita, T., H. Kawaguchi, S. Mizutani, and M. Tsuchida. 1991. Histiocytic medullary reticulosis, a lethal form of Epstein-Barr-virus-related disorder. Lancet. 337:986-987.

10. Horwitz, C., W. Henle, G. Henle, M. Goldfarb, P. Kubic, R. Gehrz, H. Balfour, G. Fleisher, and W. Krivit. 1981. Clinical and laboratory evaluation of infants and children with Epstein-Barr virus induced infectious mononucleosis. Report of 32 patients (aged 10 months-48 months). Blood. 57:933-938.

11. Miyashita, T., M. Asada, J. Fujimoto, T. Inaba, Y. Takihara, K. Sugita, F. Bessho, T. Furukawa, and S. Mizutani. 1991. Clonal analysis of transient myeloproliferative disorder in Down's syndrome. Leukemia (Baltimore). 5:56-59.

12. Ravetch, J. V., U. Siebenlist, S. J. Korsmeyer, T. Waldmann, and P. Leder. 1981. Structure of the human immunoglobulin locus: characterization of embryonic and rearranged J and D genes. Cell. 27:583-591.

13. Furley, A., S. Mizutani, K. Weilbaecher, H. S. Dahliwal, A. M. Ford, L. C. Chan, H. V. Molgaard, B. Toyonaga, T. W. Mak, P. van den Elsen, G. Gold, C. Terhorst, and M. Greaves. 1986. Developmentally regulated rearrangement and expression of genes encoding the T cell receptor-T3 complex. Cell. 46:75-87.

14. Lefranc, M. P., A. Foster, and T. H. Rabbits. 1985. Genetic polymorphism and exon changes of the constant regions of the human $\mathrm{T}$-cell rearranging gene. Proc. Natl. Acad. Sci. USA. 83:9596-9600.

15. 1985. ISCN: An International System for Human Cytogenetic Nomenclature. D. G. Handen and H. P. Klinger, editors. Published in collaboration with Cytogenet. Cell Genet. Karger, Basel, Switzerland. Also in Birth Defects: Original Article Series. Vol. 21. No. 1. 1985. March of Dimes Birth Defects Foundation, New York.

16. Rowe, M., H. Evanse, L. Young, K. Hennessy, and A. B. Rickinson. 1987. Monoclonal antibodies to the latent membrane protein of Epstein-Barr virus reveal heterogeneity of the protein and inducible expression in virus-transformed cells. J. Gen. Virol. 68:1575-1581.

17. Jat, P., and J. R. Arrand. 1982. In vitro transcription of two Epstein-Barr virus specified small RNA molecules. Nucleic Acids Res. 10:3407-3425.

18. Berti, F., G. G. Aversa, D. Soligo, G. Catoretti, D. Delia, A. Aiello, C. Parravicini, B. M. Hall, and R. Caputo. 1991. A6: a new 45RO monoclonal antibody for immunostaining of paraffin-embedded tissues. Am. J. Clin. Pathol. 95:188-193. 
19. Schwarting, R., J. Gerdes, H. Durkop, B. Falini, S. Pileri, and H. Stein. 1989. BER-H2: a new anti-Ki-1 (CD30) monoclonal antibody directed at a formol resistant epitope. Blood. 74:1678.

20. Herbst, H., E. Steinbrecher, G. Niedobitek, L. S. Young, L. Brooks, N. Muller-Lantzsch, and H. Stein. 1992. Distribution and phenotype of EpsteinBarr virus-harbouring cells in Hodgkin's disease. Blood. 80:484-491.

21. Niedobitek, G., H. Herbst, L. S. Young, L. Brooks, M. G. Masucci, J. Crocker, A. B. Rickinson, and H. Stein. 1992. Patterns of Epstein-Barr virus infection in non-neoplastic lymphoid tissue. Blood. 79:2520-2526.

22. Stein, H., K. Gatter, H. Asbahr, and D. Y. Mason. 1985. Use of freezedried paraffin-embedded sections for immunohistologic staining with monoclonal antibodies. Lab. Invest. 52:676-181.

23. Katz, B. Z., N. Raab-Traub, and G. Miller. 1989. Latent and replicating forms of Epstein-Barr virus DNA in lymphomas and lymphoproliferative diseases. J. Infect. Dis. 160:589-594.

24. Falini, B., S. Pileri, I. D. Solas, M. F. Martelli, D. Y. Mason, G. Delsol, K. C. Gatter, and M. Fagioli. 1990. Peripheral T-cell lymphoma associated with hemophagocytic syndrome. Blood. 75:434-444.

25. Craig, F. E., N. Clare, J. Sklar, and P. M. Banks. 1991. T-cell lymphoma and the virus associated hemophagocytic syndrome. Am. J. Clin. Pathol. 97:189194.

26. Budd, R. C., J. C. Gerottini, and H. R. MacDonald. 1987. Selectively increased production of interferon gamma by subsets of Lyt-2+ and L3T4+ cells identified by expression of pgp-1. J. Immunol. 138:3583-3588.

27. Salmon, M., G. D. Kitas, and P. A. Bacon. 1989. Production of lymphokine mRNA by CD45R + and CD45R - helper T cells from human peripheral blood and by human CD4+ T cell clones. J. Immunol. 143:907-912.

28. Swain, S. L., A. D. Weinberg, and M. English. 1990. CD4+ T cell subsets: lymphokine secretion of memory cells and of effector cells that develop from precursors in vitro. J. Immunol. 144:1788-1793.
29. Imashuku, S., S. Ikushima, N. Esumi, S. Todo, and M. Saito. 1991. Serum levels of interferon-gamma, cytotoxic factor and soluble interleukin-2 receptor in childhood hemophagocytic syndromes. Leukemia and Lymphoma. 3:287-231.

30. Henter, J.-I., G. Elinder, O. Soder, M. Hansson, B. Anderson, and U. Anderson. 1992. Hypercytokinemia in familial hemophagocytic lymphohistiocytosis. Blood. 78:2918-2922.

31. Hsu, D.-H., R. W. Malefyt, D. F. Fiorentino, M.-N. Dang, P. Vieira, J. Vries, H. Spits, T. R. Mosmann, and K. W. Moore. 1990. Expression of Interleukin-10 activity by Epstein-Barr virus protein BCRF1. Science (Wash. DC). 250:830-833.

32. Pileri, S., B. Falini, M. F. Martelli, H. Stein, P. Baglioni, S. Poggi, D. Y. Mason, G. Delsol, and A. G. Stansfeld. 1990. Lymphohistiocytic T-cell lymphoma (anaplastic large cell lymphoma CD30+/Ki-1 + with a high content of reactive histiocytes): a clinical, pathological and immunohistological study of 13 cases. Histopathology (Oxf.). 16:383-391.

33. Boos, H., M. Stoehr, M. Sauter, and N. Muller-Lantzsch. 1990. Flow cytometric analysis of Epstein-Barr virus (EBV) latent membrane protein expression in EBV-infected Raji cells. J. Gen. Virol. 71:1811-1816.

34. Henderson, S., M. Rowe, D. Croom-Carter, F. Wang, L. Longnecker, F. Kieff, and A. B. Rickinson. 1991. Induction of bcl-2 expression by Epstein-Barr virus latent membrane protein 1 protects infected $B$ cells from programmed cell death. Cell. 65:1107-1115.

35. Harabuchi, Y., N. Yamanaka, A. Kataura, S. Imai, T. Kinoshita, F. Mizuno, and T. Osato. 1990. Epstein-Barr virus in a nasal T-cell lymphomas in patients with lethal midline granuloma. Lancet. i:128-131.

36. Kikuta, H., Y. Taguchi, K. Tomizawa, K. Kojima, N. Kawamura, A. Ishizaka, Y. Sakiyama, S. Matsumoto, S. Imai, T. Kinoshita et al. 1988. EpsteinBarr virus genome-positive $T$ lymphocytes in a boy with chronic active EBV infection associated with Kawasaki-like disease. Nature (Lond.). 333:455-457. 